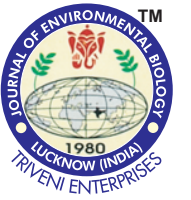

\title{
The effect of agricultural land use on soil erosion processes at upland landscape in Slovakia
}

\section{Authors Info}

\section{Petlušová*, P. Petluš and} J. Hreško

Department of Ecology and Environmental Sciences, Faculty of Natural Sciences, Constantine the Philosopher University in Nitra, Nitra, 94974 , Slovakia

*Corresponding Author Email : vpetlusova@ukf.sk

Key words Agricultural land, Land use changes, Morphometric relief properties, Water erosion

\section{Publication Info}

Paper received : 20.08.2016

Revised received : 25.06 .2017

Accepted : 28.06.2017

\section{Abstract}

Aim: Water erosion has the biggest impact on soil degradation in Slovakia. It occurs mainly on arable land at upland type of country. The morphometric segmentation of uplands together with different land use fastens the erosion processes. The aim of the study was to identify the erosion effects of agricultural land use in selected upland localities in Slovakia based on alterations in land use and morphometric relief properties.

Methodology: The model area represents intensively used agricultural land at Hronskápahorkatina upland, Slovakia. Identification of erosion processes is based on historical and current land use by using the methodology assessment of land use change. Erosion processes were assessed based on from 1949 to 2015 and verified in field. 11 categories of land use change types were set. The process of intensification, preservation (no change) and extensification using high, middle and low type of change intensity was evaluated. The occurrence of high intensification process was observed to by the most common among them. By Kruskal-Wallis ANOVA test we confirmed the reason between the type of land use change and spatial distribution of increasing areas with soil erosion was also examined. Synthesis of land use changes, types and slope categories were used to assess areas with low, middle and high soil erosion potential.

Results: We identified processes in the study area. Intensification was found on $53 \%$ of agricultural landscape in the study area. Extensification was found on $3.86 \%$ of agricultural landscape. The spatial effect of water erosion increase of $8.88 \%$ in the years of 1949 to 2015 . Water erosion risk areas represented 408.44 ha $(27.78 \%)$.The areas with high potential cover 413.35 ha of agricultural land. Out of that 130.71 ha $(31.62 \%)$ were eroded. These areas are currently used as large scale arable fields.

Interpretation: Land use management in the observed area was found to be evaluated not suitable, especially the homogenous and historically not justifiable layout of agricultural landscape. Based on the results we recommend preparation of a new layout for the agricultural landscape which will reflect the principles mechanism of landscape ecology of optimisation of agricultural land use.

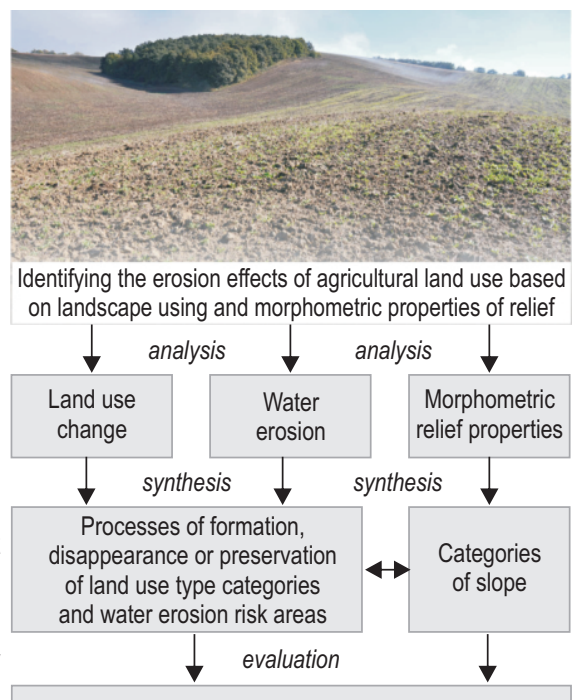

Effect of land use change on water erosion

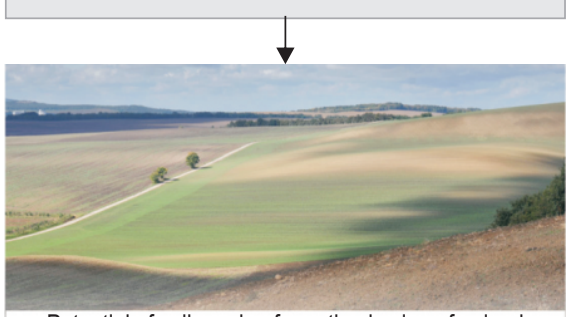

Potential of soil erosion for optimal using of upland agricultural land 


\section{Introduction}

Water erosion is one of the most common cause of soil degradation in Slovakia. The erosion degradation process is significantin an upland type of landscape. The uplands in Slovakia have suitable climatic and edaphic conditions for agricultural land use. The uplands in the Slovak low land were intensively have been by agricultural practices since early Palaeolithic, which is well documented by various archaeological surveys (Pavúk and Karlovský, 2004). In the 50 s, of the $20^{\text {th }}$ century, major changes in agricultural land use and practices occurred alongside new socioeconomic changes (change of political regime from capitalism to socialism), one of them being changes in the size of the agricultural plots. The process of intensification and land unification took place. Land use types contributing to faster surface runoff of rainwater were widely implemented.

Many studies were dedicated to the issues of soil degradation, projects of erosion control or to landscaping. Among studies dedicated to water erosion in agricultural landscape are the works of Zachar (1982), Fulajtár and Janský (2001), Stankoviansky $(1998,2000)$, Janeček (2012). The origin of water erosion is conditioned mainly by morphological and morphometric relief properties. Panagos et al. (2015), Kirkby et al. (2002), Styk and Pálka (2015), Pelacani et al. (2008), Šinka (2008) examined the influence of morphometric relief properties on water erosion. Ružička and Ružičková (1973), Pucherová et al. (2007), Muchová and Petrovič (2010), Lieskovský and Kenderessy (2014) referred to the influence of morphometric relief properties (slopes) affecting the formation of water erosion. These authors also emphasized the effects of land use on water erosion occurrence as one of the main factors.

In view of the above, aim of this paper was to identify the erosion effects of agricultural land use and land use change effects on water erosion of soils in chosen upland localities in Slovakia.

\section{Materials and Methods}

Our model area is intensively managed agricultural land and lies within the upland areas of L'ubá and Belá (Fig. 1) administration boundaries. Its current land use characterise the result of agricultural intensification. Large scale arable land with cambisols, regosols and mollic soils prevail. The area is a part of Podunajskapahorkatina upland. The segmentation of landscape has moderate to low character with altitudes from $110-250$ m above the sea level.

Aerial imagery was used to identify erosion areas and land use types in the past for the purpose of this study. Geographical Information Systems (GIS) tools were used for analysis complemented by field research (survey). Reference layer was created using vectorisation in ARC GIS (version 9.3) over which new spatial units for further analysis were created using the overlay method. The land use change types and morphometric relief parameters (slope) were included in the assessment process. The selection of the area was determined by presence of significant erosion processes. The assessment of spatial distribution of erosion and accumulation areas was undertaken through visual analysis and interpretation of aerial imagery. Areas with the most significant effect of erosion were verified by 7 soil samples. Soil sampler Edelman with drilling depth down to $120 \mathrm{~cm}$ and $50 \mathrm{~mm}$ circumference was used.

The strength of humus layer, presence of soil layers, depth of tillage, character of substrate and strength of the accumulated materials were all verified. At the same time, occurrence of soil types and subtypes classified in the system of soil-ecological units.

For comparison of land use changes (from 1949 to 2015) 11 land use types were set according to Ružička and Ružičková (1973) : Small scale arable fields, combined fields (combination of small and large scale arable fields), large scale arable fields, vineyards, permanent grassland, orchard, wetland, water body, woodland, build-up area, roads. Only agricultural land and woodlands were included in the change assessment exercise.

The changes were expressed as processes, which indicate formation, disappearance or preservation of land use type categories. Intensity of change type was identified during the process of intensification and extensification as: high, moderate or low. Indicative processes of land use change categories were modified according to Cebecauerová (2007), Míchal (1992). According to Míchal (1992), the level of ecosystem's natural state is a value, which is indirectly causal to the level of human influence on this system.

Criteria for assessment of land use change processes : For the purpose of applicability of the work results Land Parcel Identification System (LPIS) - register of agricultural production blocks was used for assessment of the land use change processes. According to LPIS, the total area of agricultural land in the study area is $1470.14 \mathrm{ha}$.

Process of intensification : Negative qualitative change of ecological stability. Ecological stability decreased e.g. by turning small scale arable fields in to a large scale arable fields or vineyards. In this process the intensity of the change type reflected in qualitative change of stable land type into an unstable one.

High intensification : very significant negative qualitative change of landscape type into very unstable ecological landscape type, e.g. transformation of small scale arable fields into large scale arable fields.

Moderate intensification : significant negative qualitative change of landscape type into an unstable or less stable ecological landscape type, e.g. transformation of small scale 
arable fields into vineyards or combined fields into large scale arable fields, or transformation of woodlands into vineyards.

Low intensification: Less significant negative qualitative change of landscape type into less stable landscape type, e.g. the transformation of permanent grassland into vineyard, or orchard into vineyard.
Process of extensification : Positive qualitative change of ecological stability. Ecological stability is increasing, e.g. transformation of small scale arable fields into permanent grasslands. The intensity of change type reflected in qualitative change of unstable landscape type into a stable landscape type.

Low extensification: Less significant positive qualitative change

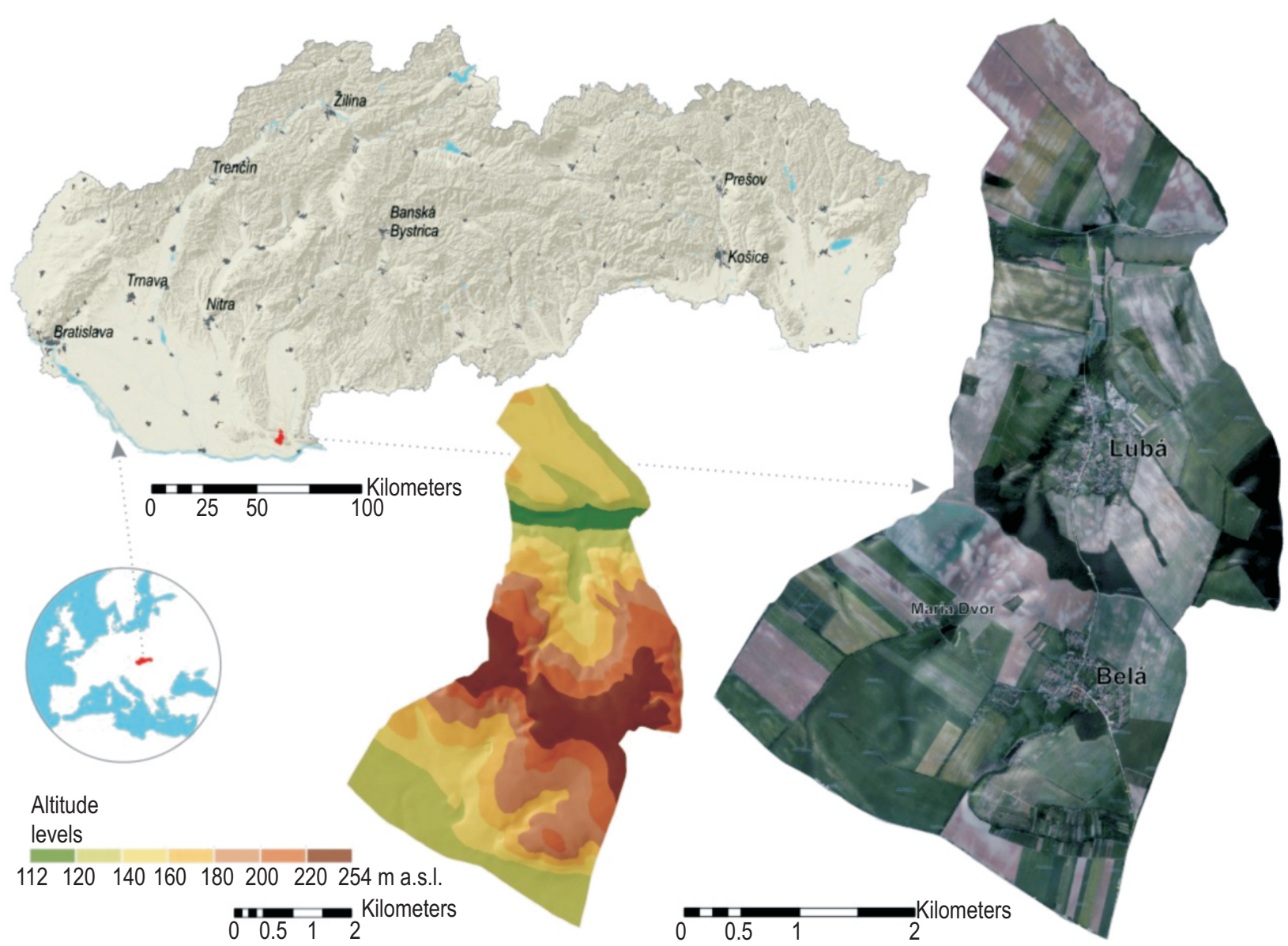

Fig. 1 : Cadastral areas of L'ubá a Belá (NovéZámky municipality, Slovakia)

Table 1 : Potential of soil erosion based on land use change and slopes

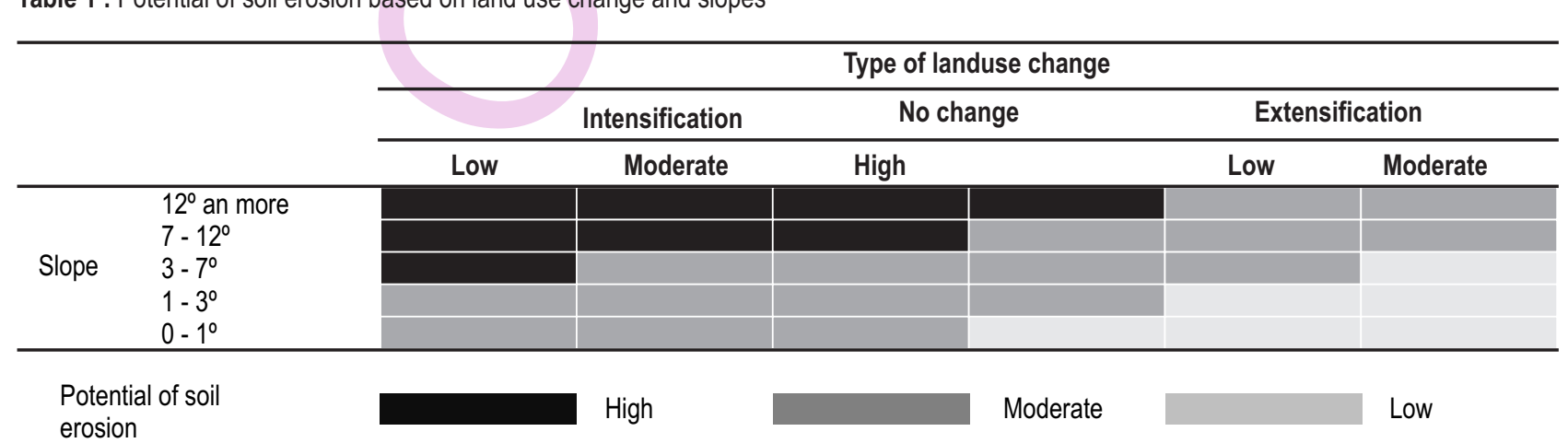


Table 2: The prevalence of land use type categories in the area in years 1949 and 2015

\begin{tabular}{|c|c|c|c|c|}
\hline \multirow[t]{2}{*}{ Land use type category } & \multicolumn{2}{|c|}{ y. 1949} & \multicolumn{2}{|c|}{ y. 2015} \\
\hline & ha & $\%$ & ha & $\%$ \\
\hline Small scale arable fields & 735.04 & 40.65 & 41.38 & 2.29 \\
\hline Combined fields & 120.34 & 6.65 & 0.00 & 0 \\
\hline Large scale arable fields & 620.56 & 34.31 & 1279.26 & 70.74 \\
\hline Vineyards & 45.88 & 2.54 & 162.50 & 8.98 \\
\hline Permanent grasslands & 79.04 & 4.37 & 51.04 & 2.82 \\
\hline Orchards & 11.98 & 0.66 & 0.00 & 0 \\
\hline Woodlands & 89.92 & 4.97 & 110.05 & 6.08 \\
\hline Others & 105.83 & 5.85 & 164.36 & 9.09 \\
\hline Total & 1808.59 & 100 & 1808.59 & 100 \\
\hline
\end{tabular}

of landscape type into ecologically stable landscape type, e.g. small scale arable fields into permanent grasslands.

Moderate extensification : Significant positive qualitative change of landscape type into ecologically less stable or stable landscape type e.g. large scale arable fields turning into permanent grasslands, vineyards turning into small scale arable fields.

High extensification : A significant positive qualitative change of landscape type into stable landscape type e.g. large scale arable fields into a woodland.

Preservation: No qualitative change of land use occurred. All landscape types remained unchanged, e.g. small scale arable fields, large scale arable fields, permanent grasslands or vineyards.

Land use change and slopes as factors affecting the potential of soil erosion : The assessment took place at erosion localities. Aerial imagery from 6 different years $(1949,1970,2006$, 2011, 2014, 2015) was used to visual identify the erosion localities. The imagery is from different seasons, which partially eliminates the effect of vegetation cover (seasonal visual effect of erosion overlay). Spatial assessment of quantitative occurrence of erosion localities was obtained through vectorisation of bright amoebic shapes in the aerial imagery. Areas with past erosion and current erosion, or areas with past erosion only or areas with current erosion only were selected. They were examined as areas affected or potentially affected by water erosion in the following assessment. After that the effect of land use change on spatial distribution of areas affected by water erosion was assessed. For statistical verification the non-parametric Kruskal-Wallis ANOVA test was used.

Slopes as significant morphometric characteristic causing the occurence of erosion were assessed. The aim was to find areas, where the erosion process does not occur only as an effect of agricultural land use, but also as an effect of slopes. 5 categories of slopes were used: $0-1^{\circ}, 1-3^{\circ}, 3-7^{\circ}, 7-12^{\circ}, 12^{\circ}$ and more. Using synthesis of the categories (intensity of land use change, slopes and areas with water erosion risk) 3 types of soil erosion potential categories were created: high, moderate and low (Table 1).

Land use was assessed in two different time horizons (1949 and 2015). These reflect the most significant changes in the intensity of land use for 11 categories of land use present in both horizons. For the purpose of agricultural land use assessment the categories of wetlands, water bodies, build-up areas and roads were merged into "others". The reason was that these land use types are not used in agricultural practices. Woodland, on the other hand, was included and that is inspite of the fact that it is not primarily an agricultural land. The reason is that in some parts of the area the woodlands were transformed into agricultural land. The prevalence of land use type categories in the respective years is showed in Table 2.

The total area of agricultural land is determined by the transformation of agricultural land use to areas with private residences, which were built up in $50 \mathrm{~s}-60 \mathrm{~s}$ of the $20^{\text {th }}$ century. In 1949 small scale arable fields, combined fields and large scale arable fields prevailed in the area. By 2015 the small scale arable fields almost disappeared on account of prevalent large scale arable fields. Combined fields disappeared completely. This was caused by new socioeconomic arrangements in 1949 and 1950 continued with collectivization (the process of land consolidation during socialism) in 1965 under which all the agricultural land from 4 surrounding villages was transformed into large scale arable fields. The land use changes are connected to it (Fig. 2).There was a decrease of the of small scale arable fields of 693.66 ha $(94.37 \%)$, combined fields of 120.34 ha $(100 \%)$, permanent grasslands of 28.00 ha $(35.42 \%)$ and orchards of $11.98 \mathrm{ha}(100 \%)$ in the observed period of $1949-2015$.

We noted that the area of large scale arable fields increased to 658.70 ha $(51.49 \%)$, vineyards increased to 116.62 ha $(71.76 \%)$, woodlands of 20.13 ha $(18.29 \%)$ and the "others" category increase of 58.53 ha $(35.61 \%)$. 


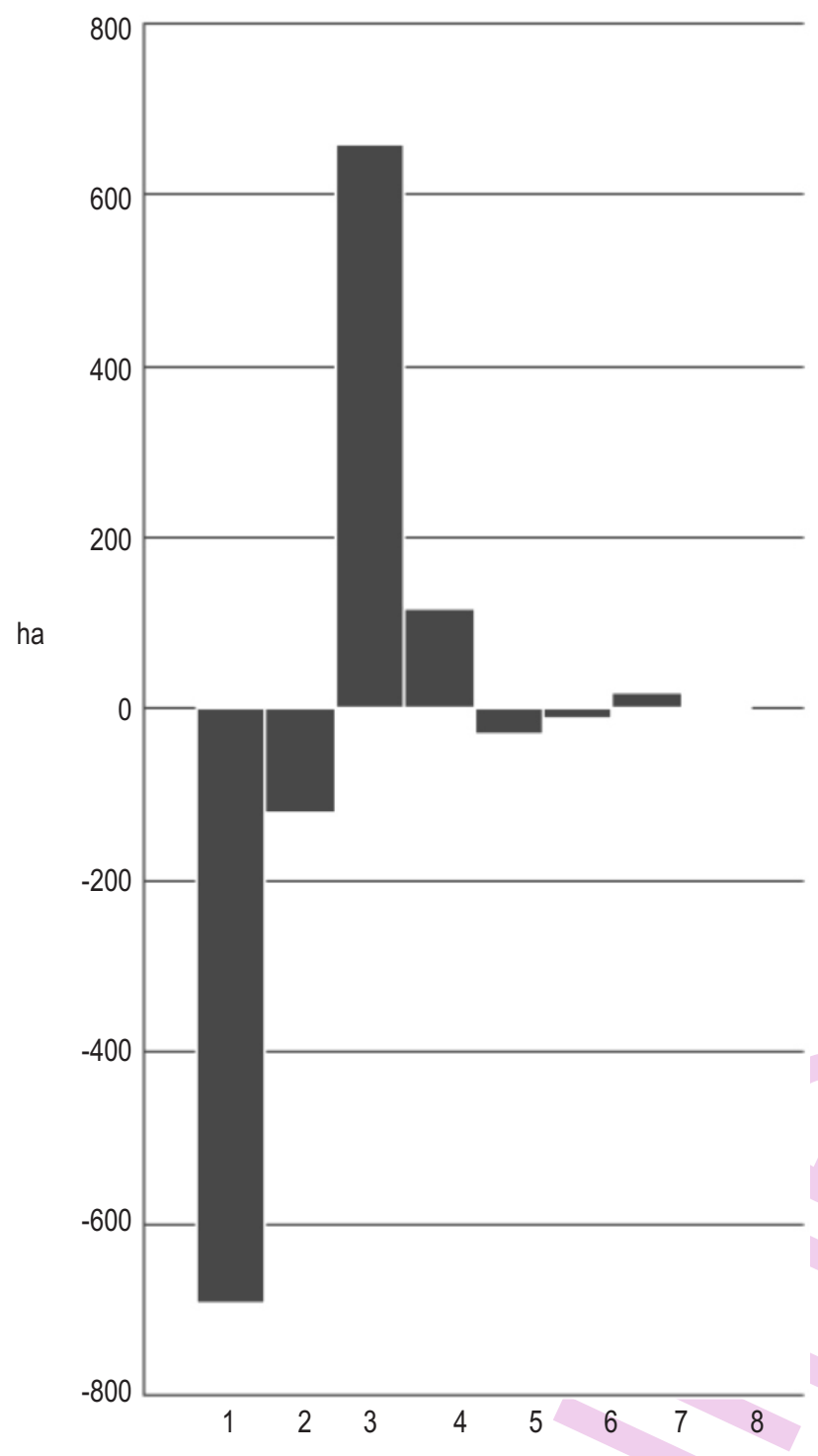

Fig. 2 : Land use changes in $1949-2015$

\section{Results and Discussion}

Based on the verification of erosion processes and utilisation of soil samples, we found that the study area's most common soil type isregosol. Regosols are prone to erosion process on steeper slopes with neogen substrate. Different soil types are also common: eroded chernozem, cambisolic chernozem, eroded cambisol. Based on these soil types it can be assumed that chernozem and cambisols were common in the study area, but were degraded to regosols due to erosion processes and intensive land use change. The soil erosion is apparent from the $\mathrm{C}$ horizon, which was significantly brighter than higher horizons and from accumulated soils in the concave parts of the slope.

Assessment of land use change processes : Assessment of land use change processes is shown in Table3. It presents those processes, which were identified in the study area. Both intensification and extensification processes occurred during the study time period. Intensification was found on 781.49 ha, which represents $53.15 \%$ of all agricultural landscape in the study area. Extensification was found on 56.71 ha, which represents 3.86\% of agricultural landscape. In an area of 631.94 ha (42.99\%) no land use change was identified and the original land use remained unchanged. The intensity of the change type is presented in Fig. 3.

High intensification is linked to the change from small scale arable fields and woodlands into large scale arable fields. This change was influenced by the change of land ownership, which shifted from private owners to state ownership. Effectivity of the agricultural system was based on its intensive land use. The small scale arable fields got practically extinct. The area of arable land increased on the account of woodlands. These changes were often implemented on account of the ecological stability of the landscape with development of risk factors such as water erosion.

Spatial distribution of water erosion : Identification of erosion processes was done visually on real imagery (Fig. 4). Based on visual assessment of the aerial photography, erosion was identified in all studied time periods. Using vecorisation of bright amebic elements in the pictures, areas of water erosion were identified. The spatial effect of water erosion increased of 130.56 ha $(8.88 \%)$ in the year 1949 to 2015 . The increase was caused by land use e.g. the transformation of multiple small scale arable fields into large scale arable field. Water erosion risk areas represented 408.44 ha $(27,78 \%)$.

After that the effect of land use change types on spatial distribution of areas showing signs of water erosion was assessed. The non-parametric Kruskal-Wallis ANOVA test was used to assess the causality. Evidential influence of the land use (Kruskal Wallis: $\mathrm{H}=5, \mathrm{~N}=1205, \mathrm{p}<0.001$ ) on spatial water erosion occurrence was found (Fig. 5). 1205 areas affected by water erosion risk under 6 different land use change types were tested through statistical assessment. Based on the results it is apparent that land use change type is evidentially affecting spatial distribution of water erosion in all categories of land use change types. It is mainly the process of high intensification, which has a high influence on distribution of erosion. The influence is decreasing in the line from high through moderate to low intensification. The highest relation between the land use change type and spatial erosion distribution occurs in case of no change of land use. The study area has been used intensively in the long term. Intensification process was implemented before 1949 and it continues till now. The causality between the land use change type and spatial erosion distribution is highly evidential. Lower values of relation were identified for extensification process. It is linked to prevalence of vegetation cover, which eliminates erosion. 
Table 3 : Assessment of land use change processes

\begin{tabular}{|c|c|c|c|c|c|}
\hline The type of change & Intensity of the change & ha & $\%$ & y.1949 & y.2015 \\
\hline \multirow[t]{3}{*}{ Intensification } & High & 611.06 & 41.56 & $\begin{array}{l}\text { Small scale arable fields } \\
\text { Woodlands }\end{array}$ & $\begin{array}{l}\text { Large scale arable fields } \\
\text { Large scale arable fields }\end{array}$ \\
\hline & Moderate & 142.82 & 9.71 & $\begin{array}{l}\text { Small scale arable fields } \\
\text { Combined fields } \\
\text { Woodlands } \\
\text { Permanent grasslands } \\
\text { Orchards } \\
\text { Vineyards }\end{array}$ & $\begin{array}{l}\text { Vineyards } \\
\text { Large scale arable fields } \\
\text { Vineyards } \\
\text { Large scale arable fields } \\
\text { Large scale arable fields } \\
\text { Large scale arable fields }\end{array}$ \\
\hline & Low & 27.61 & 1.88 & $\begin{array}{l}\text { Permanent grasslands } \\
\text { Orchards }\end{array}$ & $\begin{array}{l}\text { Vineyards } \\
\text { Vineyards }\end{array}$ \\
\hline No change & - & 631.94 & 42.99 & $\begin{array}{l}\text { Small scale arable fields } \\
\text { Large scale arable fields } \\
\text { Permanent grasslands } \\
\text { Vineyards }\end{array}$ & $\begin{array}{l}\text { Small scale arable fields } \\
\text { Large scale arable fields } \\
\text { Permanent grasslands } \\
\text { Vineyards }\end{array}$ \\
\hline Extensification & $\begin{array}{l}\text { Low } \\
\text { Moderate }\end{array}$ & $\begin{array}{l}8.18 \\
48.53\end{array}$ & $\begin{array}{l}0.56 \\
3.30\end{array}$ & $\begin{array}{l}\text { Small scale arable field } \\
\text { Large scale arable fields } \\
\text { Large scale arable fields } \\
\text { Large scale arable fields } \\
\text { Vineyards }\end{array}$ & $\begin{array}{l}\text { Permanent grasslands } \\
\text { Permanent grasslands } \\
\text { Vineyards } \\
\text { Small scale arable fields } \\
\text { Permanent grasslands }\end{array}$ \\
\hline
\end{tabular}

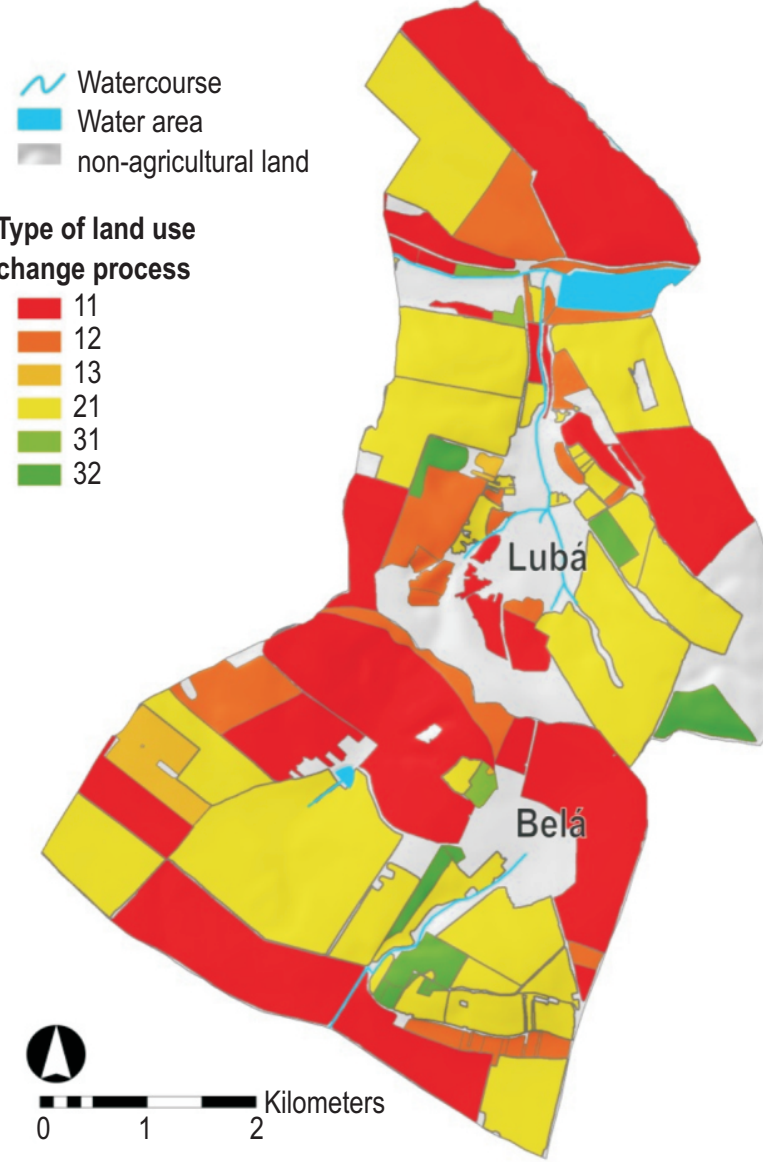

Fig. 3 : Types of land use changes; Legend: 11 high intensification, 12 moderate intensification, 13 low intensification, 21 no change, 31 low extensification, 32 moderate extensification
The effect of slope and land use on water erosion : Areas with low, moderate and high potential of water erosion were determined by using synthesis of the intensity of the type of change, slopes and areas with water erosion risk (Fig. 6). The areas with high potential cover 413.35 ha of agricultural land. Out of that 130.71 ha $(31.62 \%)$ are eroded. These areas are currently used as large scale arable fields. They are most significant in the northern part of Belácadastre (Fig. 7). The large scale arable fields were placed in vertically diverse terrain. The formation of these fields can be traced back to after 1949. They were transformed from small scale arable fields. Strong effect of the erosion is linked to land use change.

Another compact area with high soil erosion potential lies in the northern region of the L'ubá village cadastre. It is mainly intensively used large scale arable land on slopes oriented to south-east. Moderate potential was identified on 945.27 ha, out of which 245.54 ha $(25.97 \%)$ are eroded areas. Those are vertically less diverse areas. The area is used as large scale arable field. Parts of it are also permanent grasslands, vineyards or remnants of the small scale arable fields. Low potential is on 111.50 ha, out of which only 19.47 ha $(17.46 \%)$ are eroded. The spatial distribution is heterogenous. The area is used as vineyeards, permanent grasslands and remnants of small scale arable fields and gardens. The lowest erosion effect coincides with a long term presence of ecostabillisatory landscape elements.

Water erosion represents serious ecological, environmental and economic problem. This natural event of soil particles movement and their accumulation can be altered by land use. Past surveys were focused on effects of water erosion in relation to land use (Stankoviansky, 2003; Fulajtár et al., 2013; 

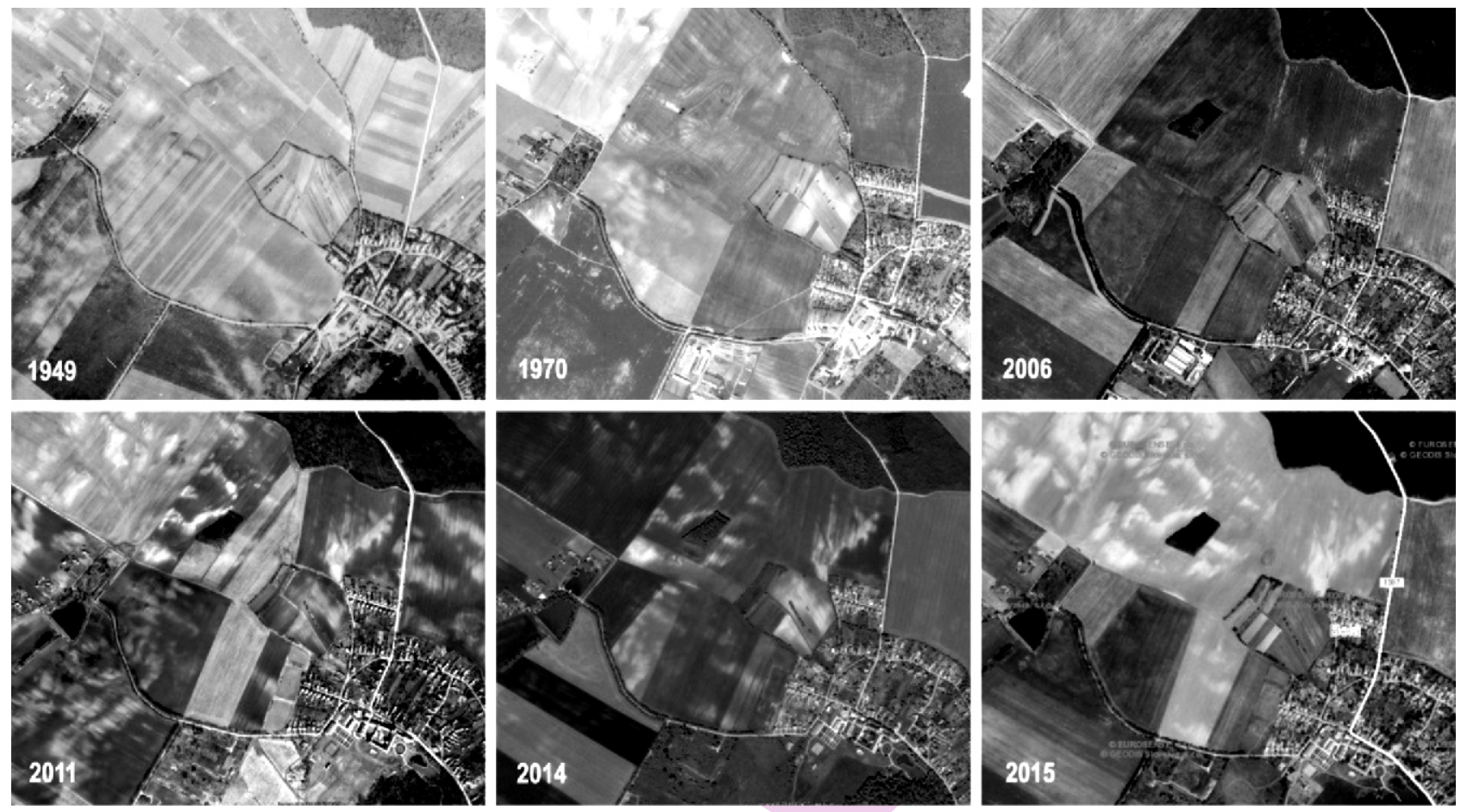

Fig. 4 : Vissual effects of water erosion in the year 1949, 1970, 2006, 2011, 2014, 2015 in north-west part of Belá; Historical aerial image @Topografickýústav Banská Bystrica, Orthophotomaps@ Eurosence, s.r.o., @ Geodis Slovakia, s.r.o.

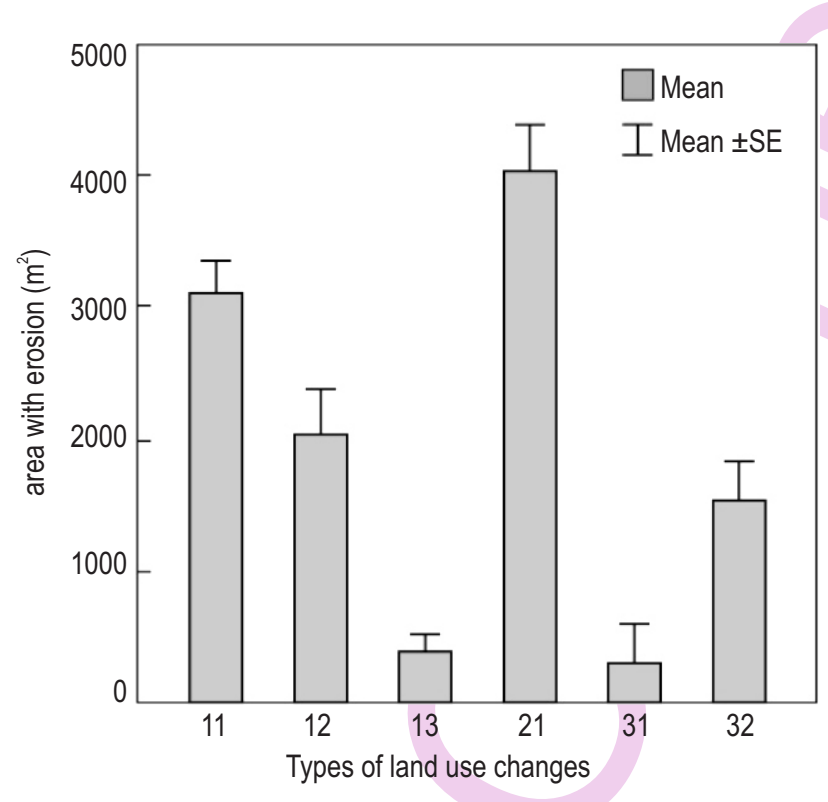

Fig. 5 : Effect of land use change on spatial water erosion occurence (Kruskal-Wallis: $\mathrm{H}=5, \mathrm{~N}=1205, \mathrm{p}<0,001$ ); Legend: 11 high intensification, 12 moderate intensification, 13low intensification, 21 no change, 31 low extensification, 32 moderate extensification

Fulajtár, 2002). These showed a direct effect of land use on water erosion distribution. Land use is considered as agricultural activity on arable land (especially intensive large scale arable fields).
In this study we have focused on assessment of the effect of land use change types on the formation and distribution of soil erosion. By land use change type we understood the process of its use since 1949 till 2015. In the past, small scale farming dominated the area's land use. This type of land use stabilises the arable land and eliminates various soil erosion processes. The permanent grasslands, vineyards and orchards were also more common in the past. They all have a higher coefficient of ecological stability. The landscape was therefore affected by lowered ecological stability, which we link to spatial distribution of erosion areas. Other factors of the erosion development are morphometric relief properties. The area is vertically diverse, which makes it prone to soil erosion. The area was stabilised for a long time by heterogeneous land use (presence of diverse land use). Nowadays it has a homogenous character. The arable land is stabilised by the presence of various vegetation cover, which eliminates the transport of soil elements, only marginally. We have verified that slopes have a significant effect on distribution of erosion areas. Intensively used arable land is implemented on slopes $7^{\circ}$ and more. That is in contrast with principles of optimal and sustainable use of arable land. We assume that the terrain orientation is also affecting distribution of soil erosion. South oriented slopes are suitable for growing heat tolerant agricultural crops. These slopes are without any vegetation cover for a long time after harvest, which in turn causes drying of the soils. Soils then become more likely to transport soil particles. Brown soils and regosols on loesses, prone to transport due to eolian forces, 


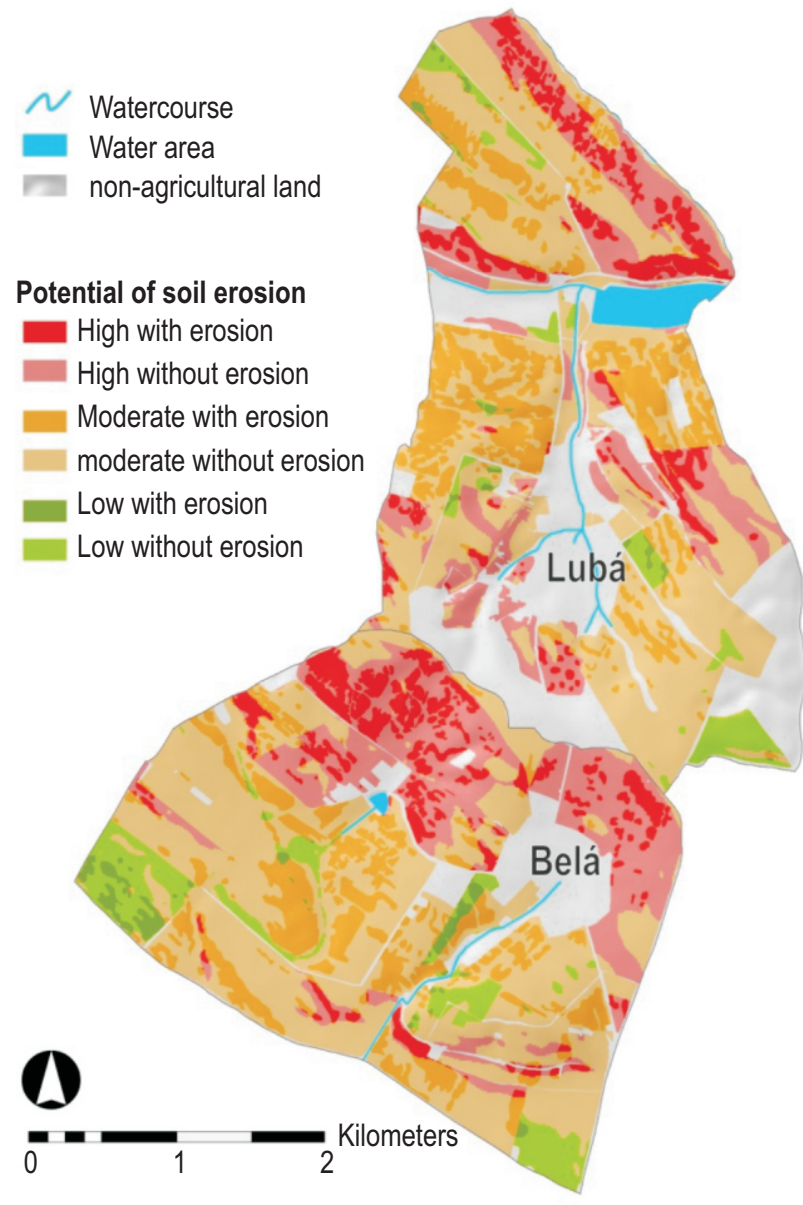

Fig. 6 : Areas with soil erosion potential

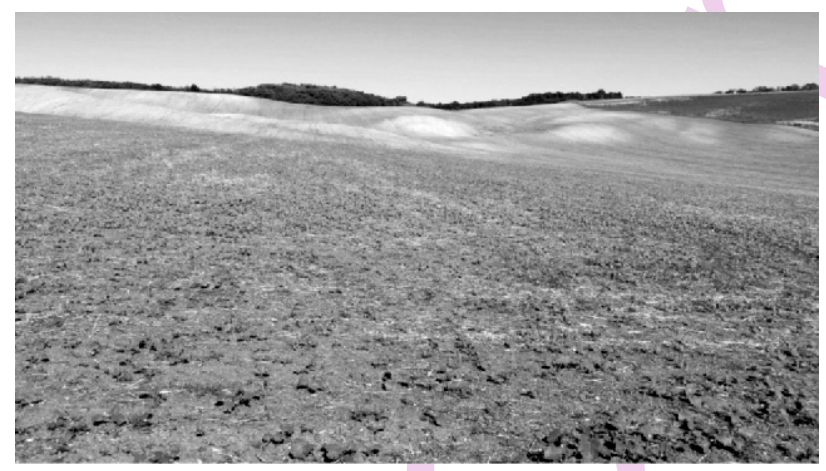

Fig. 7 : Erosion areas on agricultural landscape in the northern part of Belá village cadaster (10/2015)

are prevalent in the area. The presence of erosion on these soil types was confirmed by soil sampling.

The aim of this study was to identify signs of erosion on arable land and find out the effect of land use change types on the magnitude of water erosion. Signs of erosion were identified by aerial imagery and verified through field survey using soil samples. Using vectorisation of the aerial imagery we have identified 408.44 ha of erosion areas. We have also focused on land use change analyses from 1949 to 2015 . Based on long term land use we have selected types of land use. We assessed the process of intensification, preservation and extensification with high, moderate and low type of change intensity. Intensification process with high intensity is most common in the area $(53.15 \%)$. We have verified the relation between land use change type and the spatial distribution of areas with signs of soil erosion. Using synthesis of the land use change and slope categories we have determined areas with low, moderate and high potential of soil erosion. Based on the potential we state that the management of land use is not suitable for the study area. We consider the homogenous land use of the agricultural landas not suitable as well as the introduction of agricultural crops in these areas. We recommend preparing and implementing new organisation of the edaphic fond, which will respect the landscape-ecological principles of optimisation of land use. The new land organisation should respect historical reasons of land use. Preservation of existing eco-stabilising elements is also important. Growing agricultural crops should follow the principles of common European agricultural politics, but also respect the local assumptions for stable land use for agricultural production. We recommend diversification of agricultural crops, elimination of growings parsely sown crops and soil erosion mitigation practices.

\section{Acknowledgments}

This paper was supported by project KEGANo. 042UKF4/2014 Identification and Elimination of Erosion Processes in Agricultural Land and project VEGA No. 1/0496/16 Assessment of natural capital, biodiversity and ecosystem services in Slovakia - basis for practical implementation of integrated environmental policy.

\section{References}

Cebecauerová, M.: Analysis and assessment of changes of landscape structure. Case study of selected part lowland Borskánižina and the mountains MaléKarpaty (Analýza a hodnoteniezmien štruktúrykrajinynapríkladečastiBorskejnižiny a MalýchKarpát). Bratislava : Institute of Geography SAS. GeographiaSlovaca, 24. p. $136(2007)$.

Fulajtár, E. and L. Janský: Water erosion of soil and erosion control protection soil (Vodnáeróziapôdy a protieróznaochrana). Bratislava: Soil Science and Conservation Research Institute, p. 310 (2001).

Fulaitár, E.: Identification of severely eroded soils from remote sensing data tested in Rišňovce, Slovakia. In:Sustaining the Global Farm, Selected papers from the 10th International Soil Conservation Organisation Meeting in West Lafayette (Eds.: D.E. Stott, R.H. Mohtar and G.C. Steinardt). ISCO-USDA-NSERL-PU.p. 10751082 (2002).

Fulajtár, E., B. Hrabovská, M. Saksa, M. Sviček, I. Kováčiková and A. Morávek: Assessment of aerial photos and satelite images suitability for soil erosion mapping tested at Rišnovce site. In: 
Scientific Study of Soil Science and Conservation Research Institute (Ed.: B. Houškova) No.35. Bratislava : SSCRI, s. 41-64 (2013).

Janeček, M.: Protection erosion control of agricultural land (Ochranazemědělsképůdypřederozi). Methodics. Praha: CULS, p. 112 (2012).

Kirkby, M., L. Bracken and S. Reaney: The influence of land use, soils and topography on the delivery of hillslope runoff to channels in SE Spain. Earth Surf Proc Land, 27, 1459-1473 (2002).

Lieskovský, J. and P. Kenderessy: Modelling the effect of vegeta- tion cover and different tillage practices on soil erosion in vine- yards: $A$ case study in Vráble (Slovakia) using WATEM/SEDEM, Land Degradation \& Development., 25, 288-296, doi:10.1002/ldr.2162 (2014).

Míchal, I.: Ecological stability (Ekologickástabilita). Brno : Veronica. p.243 (1992)

Muchová, Z. and F. Petrovič: Changes in the landscape due to land consolidations, 2010. In: Ekológia (Bratislava): Int. J. Ecolo. Probl. Biosph., 29, 140-157 (2010).

Panagos, P., P. Borrelli, J. Poesen, C. Ballabio, E. Lugato, K. Meusburger, L. Montanarella and C. Alewell: The new assessment of soil loss by water erosion in Europe. Environ. Sci. Policy, 54, 438-447 (2015).

Pavúk, J. and V. Karlovský: Orientation of Lengyel rondels to directions of High and Low Moon (Orientáciarondelovlengyelskejkultúrynas meryvysokého a nízkehomesiaca). Slovak archeology, LII-2, pp. 211-280(2004).

Pelacani, S., M. Märker and G. Rudolfi: Simulation of soil erosion deposition in a changing land use: A modelling approach to implement the support practice factor. Geomorphology, 99, 329-340 (2008).

Pucherová, Z., M. Boltižiar, S. Derneš, J. Hreško, R. Mišovičová, M. Ružička and K. Tuhárska: Landscape sekondary structure methodological manual for mapping. (Druhotnákrajinnáštruktúra). Nitra: CPU, p. 124 (2007).
Ružička, M. and H. Ružičková: Landscape sekondary structure us criterion of biological balance (Druhotnáštruktúrakrajinya kokritérium biologic kejrovnováhy). Quaestionesgeobiologicae/ Biology Landscape Problems, 12, pp. 23-62(1973).

Societaspedologicaslovaca. Morphgenetic Soil Classification System of Slovakia (MorfogenetickýklasifikačnýsystémpôdSlovenska). Bratislava: NAFC SSCRI, p. 96 (2014).

Stankoviansky, M.: Evolution of operation of runoff processes in the territory of Slovakia and their geomorphic effect (Vývojpôsobenia ronovýchprocesovnaúzemíSlovenskaaichgeomorfologický efekt). Geografickýčasopis, 50, 235-246(1998).

Stankoviansky, M.: Differentiated geomorphic effect of gully erosion due to large scale land use changes. In: Geomorphology of the Carpatho-Balcan Region. Proceedings of the Carpatho-Balcan Conference, Baile Herculane, Orsova, Drobeta Turnu Severin, Romania, October 11-17, Bucuresti (CORINT) (Eds.: D. Balteanu, M. Ielenicz and N. Popescu), pp. 187-200 (2000).

Stankoviansky, M.:Geomorphic response to environmental changes in the territory of the Myjava Hill Land (Geomorfologickáodozva environmentálnychzmiennaúzemíMyjavskejpahorkatiny). Bratislava:UC. p. 152 (2003).

Styk, J. and B. Pálka: Water erosion on agricultural land and its influence upon Hricov and Zilina water reservoirs sedimentation (Vodnáerózia v pol'nohospodárskejkrajine a jejvplyvnazanášanievodných diel Hričov a Žilina). In Proceedings of Soil Science and Conservation Research Institute no. 37 Bratislava: NAFC SSCRI, 2015, pp. 96 - 105(2015).

Šinka, K.: Creation of hydrological data for the design of anti-erosion measures in the country in GIS environment (Tvorbahydrologic kýchpodkladov pre návrhprotieróznychopatrení $v$ krajine $v$ prostredí GIS). In: Forum of Young Geoinformaticians: Proceeding of papers and presentations, May 16, 2008, pp. 1-12 (2008).

Zachar, D.: Soil erosion. Elsevier Sci. Publ. Co., Amsterdam - Oxford New York, p. 548 (1982). 